\title{
A Study of Lactate Dehydrogenase (LDH) Isoenzyme is a Biochemical Tumour Marker in Cervical Carcinoma Patients
}

\author{
N. Subramanian ${ }^{1}$, H. Mohana Krishnan ${ }^{2}$, P. Venkatachalam ${ }^{3}$ and P.A.C. Kamatchi ${ }^{1}$ \\ 1. P.G. Department of Zoology, Pachaiyappa's College for Men, Kanchipuram 631 502, \\ Tamil Nadu, India \\ 2. P.G. Division for Wildlife Biology, Govt. Arts \& Science College, Ooty, Tamil Nadu, India \\ 3. P.G. Department of Human Genetics, Sri Ramachandra Medical College and Research \\ Institute (Deemed University), Chennai, Tamil Nadu, India
}

KEYWORDS Squamous Cell Carcinoma. Electrophoretic Mobility. Serum and Cervix Tissue

\begin{abstract}
To establish Lactate dehydrogenase (LDH) isoenzyme is a biochemical tumor marker in cervical carcinoma patients for diagnosis and treatment monitoring of the disease. The Serum and cervical tissue LDH isoenzyme was analyzed qualitatively by Poly Acrylamide Disc Gel Electrophoresis method. The total LDH activity was estimated quantitatively by the method of UV spectrophotometry. 50 untreated cervical carcinoma patients were taken up and compared with age matched healthy females (controls). Out of 50 patients, 5 patients were histologically classified as well differentiated squamous cell carcinoma (Grade-I), 23 were moderately differentiated squamous cell carcinoma (Grade-II) and 22 were poorly differentiated squamous cell carcinoma (Grade-III). Grade-I patients did not show any change, in the serum and cervical tissue LDH isoenzyme fractions compared to the controls but variation in electrophoretic mobility have been observed. Grade-II patients showed two new additional isoenzyme fractions in $\mathrm{LDH}_{2}$ and $\mathrm{LDH}_{3}$ locations, where as Grade-III patients showed only three LDH isoenzyme fractions. The total LDH activity in both serum and cervix tissue of normal individuals are $0.458 \pm 0.0796$ units $/ \mathrm{ml}$; and $0.680 \pm 0.0218$ units $/ \mathrm{mg}$. Grade-I patients did not show any change in total LDH activity (serum: $0.384 \pm 0.0404$ units $/ \mathrm{ml}$; cervical tissue: $0.589 \pm 0.0292$ units $/ \mathrm{mg} ; \mathrm{P}<0.01$ ). Grade-III patients showed much lower values (serum: $0.284 \pm 0.0109$ units $/ \mathrm{ml}$; cervical tissue: $0.327 \pm 0.043$ units $/ \mathrm{mg} ; \mathrm{P}<0.001$ ), where as Grade-II patients showed significant increase in total LDH activity (serum: $0.878 \pm 0.0531$ units $/ \mathrm{ml}$; cervical tissue: $1.296 \pm 0.0813$ units $/ \mathrm{mg} ; \mathrm{P}<0.001$ ) respectively. The results suggest that LDH isoenzyme is useful biochemical tumor marker for diagnosis and to assess the grade of malignancy.
\end{abstract}

\section{INTRODUCTION}

Cervical region is a common site of female malignancies in India with $85 \%$ of neoplasia having a mortality rate of 5\% (Nair and Pillai 1992). Various types of markers are being in use for the early diagnosis and to observe patients response to therapy while there are many diagnostic marker for early diagnosis of malignancy. Lactate dehydrogenase $(\mathrm{LDH})$ isoenzymes is of considerable interest to the biochemical oncologists. An increased levels of serum LDH in gynecological malignancies has been reported by several authors (Wright et al. 1966; Sherwin et al. 1968; Zondag and Klein 1968). Activity of lactate dehydrogenase LDH isoenzyme in blood serum was higher in case of precancerous lesion of cervix uteri than in healthy controls. This index was further increased 1.6 fold in the cases of malignancy of cervix uteri than

Corresponding Author:

Dr. N. Subramanian,

P.G. Department of Zoology, Pachaiyappa's College for Men, Kanchipuram 631 502, Tamil Nadu, India precancerous lesions (Nugamanova et al. 1981). Kumar et al. (1988) studied serum LDH isoenzyme activity in carcinoma cervix patients. They found out significant increase of $\mathrm{LDH}_{2}$ and $\mathrm{LDH}_{3}$ fractions in cervical carcinoma patients compared with control values $(\mathrm{P}<0.001)$. After radio therapy the patients showed significant lowering of $\mathrm{LDH}_{2}$ and $\mathrm{LDH}_{3}$ $(\mathrm{P}<0.001)$ in the serum. So they concluded that $\mathrm{LDH}^{3}$ isoenzyme determination in carcinoma cervix is very helpful in assessing, treatment response following radiotherapy and thus may be an important prognostic parameter. Chow et al. (1991) found that the total serum LDH in malignant ovarian tumor was $876.3( \pm 450.4)$ IU/L which was significantly higher than in benign ovarian cancer $364.8( \pm 87.9)$. Xi et al. (1994) suggested that LDH isoenzyme may be considered as a tumor marker. Von Eyben (2001) concluded that serum $\mathrm{LD}_{1}$ is useful tumor marker of testicular germ cell tumors. For patients with ovarian germ cell tumors, serum $\mathrm{LD}_{1}$ was raised more often than for patients with testicular germ cell tumors. Oladipo et al. (2002) reported that five isoenzyme of $\mathrm{LD}\left(\mathrm{LD}_{1}-\mathrm{LD}_{5}\right)$ were present in both control and 
patient sera. The serum $\mathrm{LD}_{1}$ and $\mathrm{LD}_{2}$ isoenzymes were predominant in the diseases groups (malignant and non malignant). The purpose of this study is to analyze LDH of serum and cervix tissues qualitatively and to estimate its activity quantitatively both in normal person and in patients suffering from cancer cervix so as to establish a bio-chemical relationship between LDH and cervical carcinoma in Indian population.

\section{MATERIALS AND METHODS}

A total of 50 cervical cancer patients who attended Out Patient Department (OPD) of the Government Aringnar Anna Memorial Cancer Institute and Hospital, Kanchipuram were taken up for this present study and compared with same age matched healthy women as control. All patients were examined clinically and histopathologically. The final diagnosis was made after histopathological examination. The pap smear results were not obtained when collecting the samples however, the stages of the tumor where conformed by the histopathological observation by the qualified experts. In all the 50 patients serum and cervical tissue LDH isoenzymes have been analyzed.

Percentage activity of each fraction $=$

$$
\frac{\text { Activity in fraction comprising a peak }}{\text { Activity in all the fractions }}=x 100
$$

\subsection{Qualitative Analysis}

Before the onset of treatment, blood samples from the patients were collected and serum was separated. Serum was maintained at $20^{\circ} \mathrm{C}$ in freezer until the analysis were carried out. Tissue samples were collected from the patients at the time of biopsy and the samples were homogenized with $0.1 \mathrm{M}$ phosphate buffer at $\mathrm{pH} 7.4$ and centrifuged at $10,000 \mathrm{Xg}$ for 20 minutes. Samples were taken separately in each tube of PAGE (Poly Acrylamide Disc Gel Electrophoresis) for analysis of LDH isoenzyme. The results were conformed by running duplicates.

The percentage activity of each fractions of isoenzymes were calculated by the following formula (using densitometric scanning).

\subsection{Quantitative Analysis}

The quantitative analysis of lactate dehydro- genase was assayed according to the method described by King (1965). One ml of buffered substrate and $0.1 \mathrm{ml}$ of enzyme extract was added and the tubes were incubated at $37^{\circ} \mathrm{C}$ for 5 minutes. After the incubation period, $0.2 \mathrm{ml}$ of $\mathrm{NAD}^{+}$solution was added to the test and $0.2 \mathrm{ml}$ of distilled water to the control and the incubation was continued for another 15 minutes. The reaction was then arrested by the addition of 1 $\mathrm{ml}$ of DNPH reagent and the tubes were incubated for a further period of 15 minutes at $37^{\circ} \mathrm{C}$. After the last incubation period, $7 \mathrm{ml}$ of $0.4 \mathrm{~N} \mathrm{NaOH}$ solution was added and the colour development was measured at $420 \mathrm{~nm}$ in a UV spectrophotometer. Suitable aliquotes of standard and blank were also analysed by the same procedure in normal women serum and cervix tissues and all the cervical cancer patients serum and cervix tissues. For serum analysis $0.1 \mathrm{ml}$ of sample was taken in test tube and the same procedure was followed for estimating total serum LDH activity.

\subsection{Statistical analysis}

Mean $(\bar{x})$, standard error (SE) were calculated for each patient. To understand the level of significance between normal and cancer cervix patients, Student t-test was applied (Zar 1984).

\section{RESULTS}

Among 50 patients studied, 5 patients were histologically classified as well differentiated squamous cell carcinoma (Grade-I), 23 were moderately differentiated squamous cell carcinoma (Grade-II) and 22 were poorly differentiated squamous cell carcinoma as (Grade-III). The densitometric scanning was done in each samples but the picture was not incorporated.

\subsection{Serum and Cervical Tissue LDH Activity in Normal Women}

Five $\mathrm{LDH}$ isoenzyme fractions namely $\mathrm{LDH}_{1}$, $\mathrm{LDH}_{2}, \mathrm{LDH}_{3}, \mathrm{LDH}_{4}$ and $\mathrm{LDH}_{5}$ have been observed in both serum and cervical tissue of normal women (Fig. 1 and 2). Serum LDH showed that $\mathrm{LDH}_{1}$ fraction has the highest activity (38.7\%) and $\mathrm{LDH}_{5}$ has the lowest activity (14.5\%). cervical tissue LDH showed that the $\mathrm{LDH}_{5}$ fraction has the highest activity $80.1 \%$ while the $\mathrm{LDH}_{4}$ has the slowest activity (27.8\%) (Table 1 and 2; Fig. 3 and 4). 


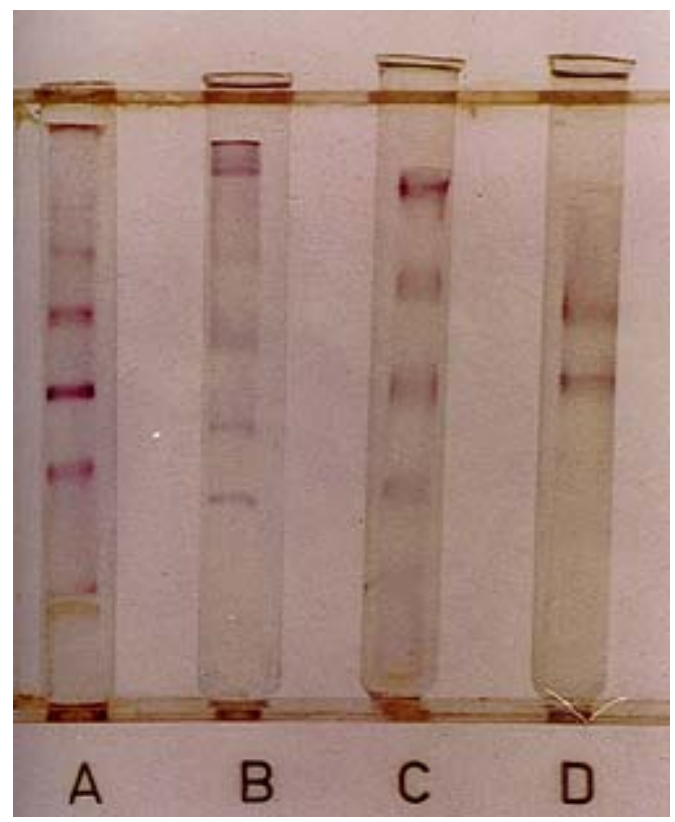

A-Normal, B-Grade I, C-Grade II, D-Grade III

Fig. 1. Electrophoretogram showing the serum LDH isoenzymes of normal woman and patients suffering from cancer cervix (Grade I, Grade II and Grade III)

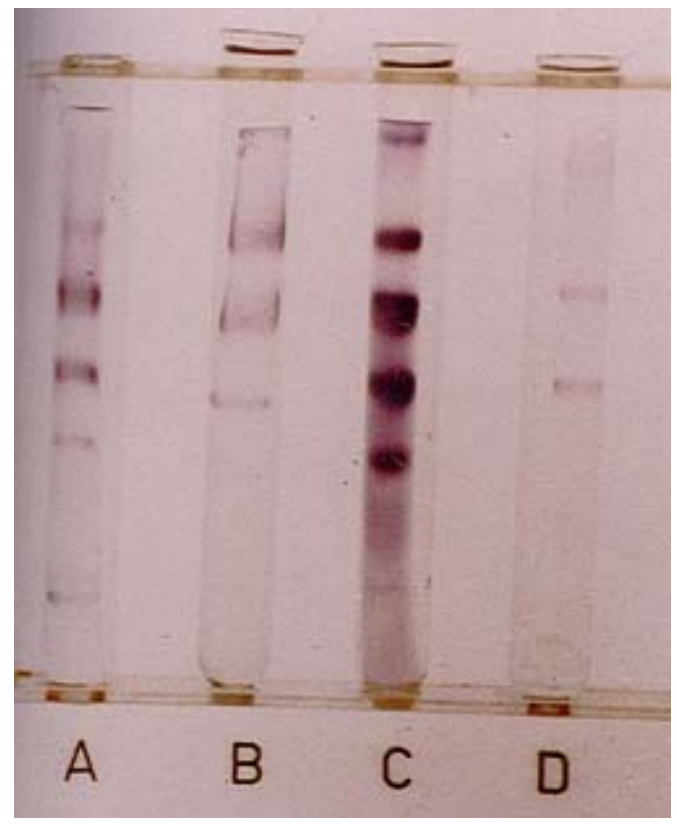

A-Normal, B-Grade I, C-Grade II, D-Grade III

Fig. 2. Electrophoretogram showing the cervix tissue LDH isoenzymes of normal woman and patients suffering from cancer cervix (Grade I, Grade II and Grade III)

Table 1: LDH isoenzyme activity (percentage of total) in sera of normal woman and patients suffering from cancer cervix (Grade-I, Grade-II and Grade-III)

\begin{tabular}{lcccc}
\hline $\begin{array}{l}\text { LDH } \\
\text { isoenzyme }\end{array}$ & $\begin{array}{c}\text { Normal } \\
\text { woman }\end{array}$ & $\begin{array}{c}\text { Well differentiated } \\
\text { squamous cell } \\
\text { carcinoma (Grade-I) }\end{array}$ & $\begin{array}{c}\text { Moderately differentiated } \\
\text { squamous cell } \\
\text { carcinoma (Grade-II) }\end{array}$ & $\begin{array}{c}\text { Poorly differentiated } \\
\text { squamous cell } \\
\text { carcinoma (Grade-III) }\end{array}$ \\
\hline $\mathrm{LDH}_{1}$ & $38.7 \pm 1.347$ & $17.6 \pm 0.632$ & $83.5 \pm 9.015$ & \\
$\mathrm{LDH}_{2}$ & $23.5 \pm 0.636$ & $22.6 \pm 0.769$ & $60.2 \pm 5.253$ & \\
$\mathrm{LDH}_{3}$ & $20.3 \pm 0.413$ & $20.0 \pm 0.736$ & $30.3 \pm 2.100$ & $55.80 \pm 5.520$ \\
$\mathrm{LDH}_{4}$ & $26.3 \pm 0.777$ & $9.20 \pm 0.182$ & $52.6 \pm 4.125$ & $18.78 \pm 1.627$ \\
$\mathrm{LDH}_{5}$ & $14.5 \pm 0.197$ & $35.7 \pm 0.046$ & $26.9 \pm 1.315$ & $24.40 \pm 1.982$ \\
\hline
\end{tabular}

Table 2: LDH isoenzyme activity (percentage of total) in cervix tissues of normal woman and patients suffering from cancer cervix (Grade-I, Grade-II and Grade-III)

\begin{tabular}{lcccc}
\hline $\begin{array}{l}\text { LDH } \\
\text { isoenzyme }\end{array}$ & $\begin{array}{c}\text { Normal } \\
\text { woman }\end{array}$ & $\begin{array}{c}\text { Well differentiated } \\
\text { squamous cell } \\
\text { carcinoma (Grade-I) }\end{array}$ & $\begin{array}{c}\text { Moderately differentiated } \\
\text { squamous cell } \\
\text { carcinoma (Grade-II) }\end{array}$ & $\begin{array}{c}\text { Poorly differentiated } \\
\text { squamous cell } \\
\text { carcinoma (Grade-III) }\end{array}$ \\
\hline $\mathrm{LDH}_{1}$ & $54.8 \pm 1.675$ & $44.6 \pm 2.625$ & $50.3 \pm 3.898$ & \\
$\mathrm{LDH}_{2}$ & $60.8 \pm 1.708$ & $35.8 \pm 2.860$ & $70.5 \pm 3.253$ & \\
$\mathrm{LDH}_{3}$ & $39.4 \pm 0.941$ & $33.7 \pm 1.885$ & $65.6 \pm 3.206$ & $63.50 \pm 5.180$ \\
$\mathrm{LDH}_{4}$ & $27.8 \pm 0.686$ & $18.5 \pm 0.713$ & $90.7 \pm 6.425$ & $44.38 \pm 3.280$ \\
$\mathrm{LDH}_{5}$ & $80.1 \pm 6.120$ & $90.7 \pm 0.450$ & $72.8 \pm 3.672$ & $35.90 \pm 2.875$ \\
\hline
\end{tabular}




\subsection{Serum and Cervical Tissue LDH Activity in Grade I Patients}

$\mathrm{LDH}$ isoenzyme fractions of the serum of Grade-I patients showed no abnormality. However a reduction in the electrophoretic mobility of LDH isoenzyme fractions and $\mathrm{LDH}_{4}$ fraction was sharply declined in its activity from $26.3 \%$ to $9.2 \%$ (Table 1 and Fig. 3 ).

LDH activity of the cervical tissue of Grade-I patients showed similar number of $\mathrm{LDH}$ isoenzyme fractions like the normal. The percentage activity of $\mathrm{LDH}_{5}$ isoenzyme fractions showed an increase from $80.1 \%$ to $90.7 \%$, where as the percentage activity of $\mathrm{LDH}_{4}$ fraction was decreased from $27.8 \%$ to $18.5 \%$ (Table 2 and Fig. 4).

\subsection{Serum and Cervical Tissue LDHActivity in Grade II Patients}

In Grade II patients, two new additional isoenzyme fractions in $\mathrm{LDH}_{2}$ and $\mathrm{LDH}_{3}$ locations with $60.2 \%$ and $52.6 \%$ were observed in the serum. The activity of $\mathrm{LDH}_{1}$ and $\mathrm{LDH}_{5}$ significantly increased from $38.7 \%$ to $83.5 \%, 14.5 \%$ to $80.1 \%$. The percentage activity of $\mathrm{LDH}_{2}$ was increased from $23.05 \%$ to $30.3 \%$ (Table 1 and Fig. 3).

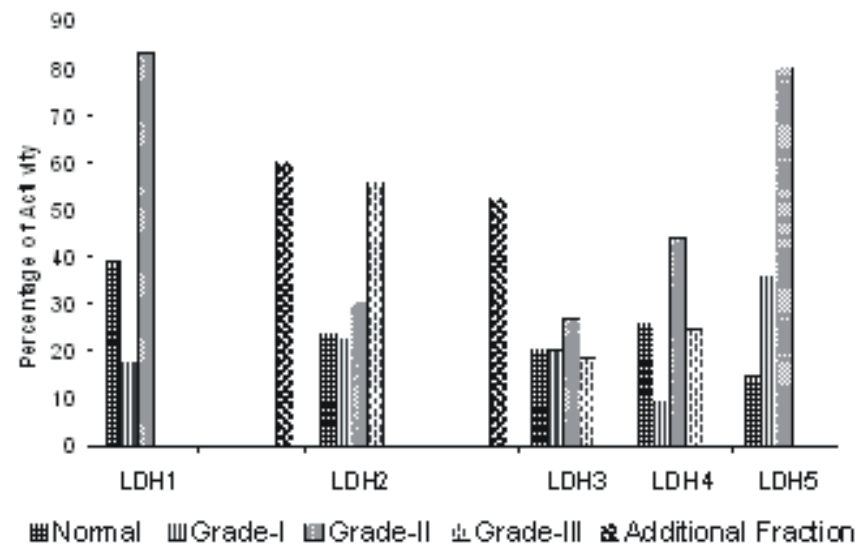

Fig. 3. LDH isoenzyme activity (percentage of total) in sera of normal woman and patients suffering from cancer cervix (Grade-I, Grade-II and Grade-III)

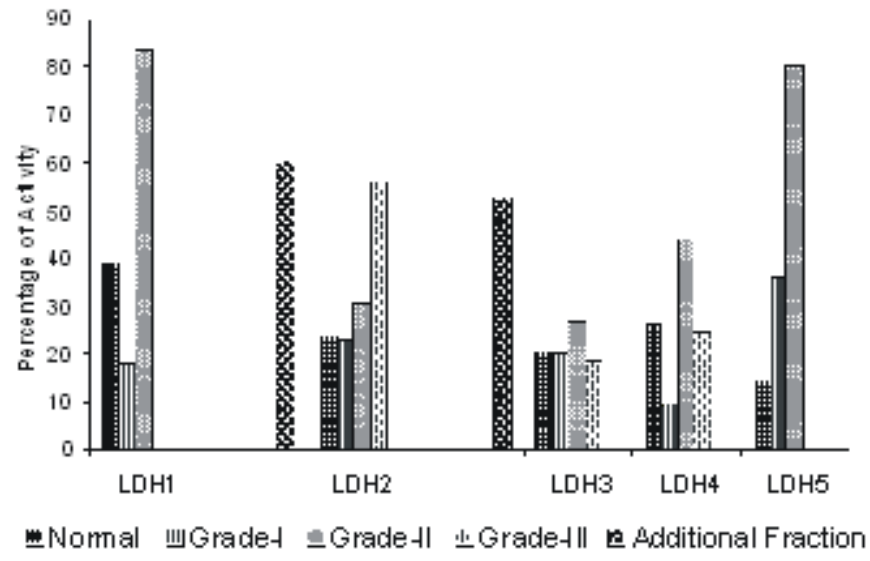

Fig. 4. LDH isoenzyme activity (percentage of total) in cervix tissues of normal woman and patients suffering from cancer cervix (Grade-I, Grade-II and Grade-III) 
Similar to serum, cervical tissue LDH activity also showed two new fractions near $\mathrm{LDH}_{2}$ and $\mathrm{LDH}_{3}$ locations. The new LDH fractions showed highest activities $70.5 \%$ and $90.7 \%$, where as the activity of $\mathrm{LDH}_{1}, \mathrm{LDH}_{2}, \mathrm{LDH}_{3}$ and $\mathrm{LDH}_{4}$ fractions were showed a marked increase but $\mathrm{LDH}_{5}$ fraction showed sharply declined its activity from $90.7 \%$ to $32.5 \%$ (Table 2 and Fig. 4).

\subsection{Serum and Cervical Tissue LDH Activity in Grade III Patients}

The serum of Grade III patients showed only three LDH isoenzyme fractions and disappearance of $\mathrm{LDH}_{1}$ and $\mathrm{LDH}_{5}$ isoenzyme fractions (Fig. 1 and 2). The activity of $\mathrm{LDH}_{3}$ and $\mathrm{LDH}_{4}$ isoenzyme fractions declined from $26.9 \%$ to $18.7 \%$ and $43.7 \%$ to $24.4 \%$ respectively, where as the $\mathrm{LDH}_{2}$ fraction increased from $30.3 \%$ to $55.8 \%$ (Table 1 and Fig. 3).

Similarly, only three LDH isoenzyme fractions were observed in cervix tissue of Grade-III patients. The fast moving $\mathrm{LDH}_{1}$ and slow moving $\mathrm{LDH}_{5}$ isoenzyme fractions are disappeared. The percentage activity of $\mathrm{LDH}_{2}, \mathrm{LDH}_{3}$ and $\mathrm{LDH}_{4}$ fractions decreased from $65.6 \%$ to $63.5 \%, 72.8 \%$ to $44.3 \%$ and $52.6 \%$ to $35.9 \%$ respectively (Table 2 and Fig. 4).

\subsection{Serum and Cervical Tissue Total LDH Activity (QuantitativeAnalysis)}

The total activity of LDH isoenzymes in both serum and cervical tissue of normal individuals were $0.458 \pm 0.796$ units $/ \mathrm{ml}$ and $0.680 \pm 0.0218$ units $/ \mathrm{mg}$ respectively. The total LDH activity of GradeI Patients were $0.384 \pm 0.04044$ units $/ \mathrm{ml}$ and $0.589 \pm 0.0292$ units/mg (Table 3 and 4). The percentage changes in both serum and cervical tissues were $-16.29 \%$ and $-13.86 \%$ respectively and this value was changed from normal individual (Fig. 5 and 6).

The activity of Grade-II patients showed higher level of total LDH in both serum and cervical tissue from $0.458 \pm 0.0796$ units $/ \mathrm{ml}$ to $0.8780 \pm .0531$ units $/ \mathrm{ml}$ and from $0.680 \pm 0.0218$ units/mg to $1.296 \pm 0.0813$ units/mg respectively. Grade-III patients showed significant reduction of total LDH activity in serum and cervical tissue from $0.458 \pm 0.0796$ units $/ \mathrm{ml}$ to $0.284 \pm 0.0109$ units/ $\mathrm{ml}$ and $0.680 \pm 0.0218$ units $/ \mathrm{mg}$ to $0.327 \pm 0.043$ units/mg respectively (Table 3 and 4 ). The percentage of changes in both serum and cervical tissue of Grade-III patients were $-37.98 \%$ and $51.83 \%$ respectively (Fig. 5 and 6).

Table 3: Total LDH activity (unit/ml) in sera of normal woman and patients suffering from cancer cervix (Grade-I, Grade-II and Grade-III)

\begin{tabular}{|c|c|c|}
\hline Normal Woman & $\begin{array}{c}\text { Well differentiated } \\
\text { squamous cell } \\
\text { carcinoma Grade-I }\end{array}$ & $\begin{array}{c}\text { Percentage of } \\
\text { Change }\end{array}$ \\
\hline $0.458 \pm 0.0796$ & $0.384 \pm 0.0404$ & $-16.29^{* *}$ \\
\hline Normal Woman & $\begin{array}{c}\text { Moderately } \\
\text { differentiated } \\
\text { squamous cell } \\
\text { carcinoma Grade-II }\end{array}$ & $\begin{array}{c}\text { Percentage of } \\
\text { Change }\end{array}$ \\
\hline $0.458 \pm 0.0796$ & $0.878 \pm 0.0531$ & $+91.37^{* * * *}$ \\
\hline Normal Woman & $\begin{array}{l}\text { Poorly differentiated } \\
\text { squamous cell } \\
\text { carcinoma Grade-III }\end{array}$ & $\begin{array}{c}\text { Percentage of } \\
\text { Change }\end{array}$ \\
\hline $0.458 \pm 0.0796$ & $0.284 \pm 0.0109$ & $-37.98^{* * *}$ \\
\hline
\end{tabular}

Table 4: Total LDH activity (unit/mg tissue) in cervix tissues of normal woman and patients suffering from cancer cervix (Grade-I, Grade-II and Grade-III)

\begin{tabular}{|c|c|c|}
\hline Normal Woman & $\begin{array}{l}\text { Well differentiated } \\
\text { squamous cell } \\
\text { carcinoma Grade-I }\end{array}$ & $\begin{array}{c}\text { Percentage of } \\
\text { Change }\end{array}$ \\
\hline $0.680 \pm 0.0218$ & $0.589 \pm 0.0292$ & $-13.86^{* *}$ \\
\hline Normal Woman & $\begin{array}{c}\text { Moderately } \\
\text { differentiated } \\
\text { squamous cell } \\
\text { carcinoma Grade-II }\end{array}$ & $\begin{array}{c}\text { Percentage of } \\
\text { Change }\end{array}$ \\
\hline $0.680 \pm 0.0218$ & $1.296 \pm 0.0813$ & $+90.58^{* * * *}$ \\
\hline Normal Woman & $\begin{array}{l}\text { Poorly differentiated } \\
\text { squamous cell } \\
\text { carcinoma Grade-III }\end{array}$ & $\begin{array}{c}\text { Percentage of } \\
\text { Change }\end{array}$ \\
\hline $0.680 \pm 0.0218$ & $0.327 \pm 0.043$ & $-51.83^{* * *}$ \\
\hline $\begin{array}{ll}\text { Mean } \pm \text { Standard } \\
* & \mathrm{p}<0.0 \\
* * & \mathrm{p}<0.0 \\
* * * & \mathrm{p}<0.0\end{array}$ & $\begin{array}{l}\text { error } \\
5 \\
1\end{array}$ & \\
\hline
\end{tabular}

\section{DISCUSSION}

The study revealed a decrease in $\mathrm{LDH}$ in the serum of Grade I cervical cancer patients indicating the onset of malignancy (Goldman et al. 1960). These variations of serum LDH isoenzymes are being used as markers. The electrophoretic mobility of all the fractions of cervix tissue showed a significant increase suggesting the impact of malignant cancer on LDH fractions. (Wright et al. 1966). 


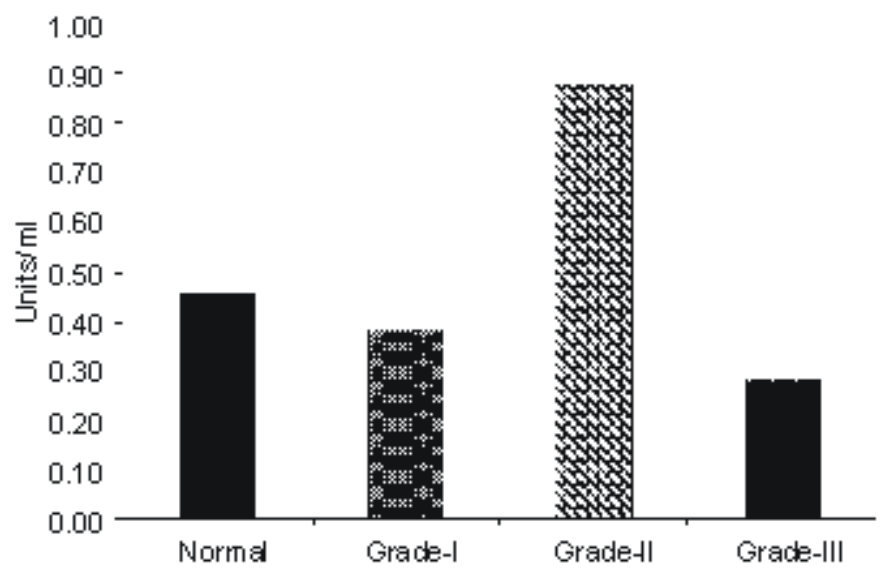

Fig. 5. Total LDH activity (unit/ml) in sera of normal woman and patients suffering from cancer cervix (Grade-I, Grade-II and Grade-III)

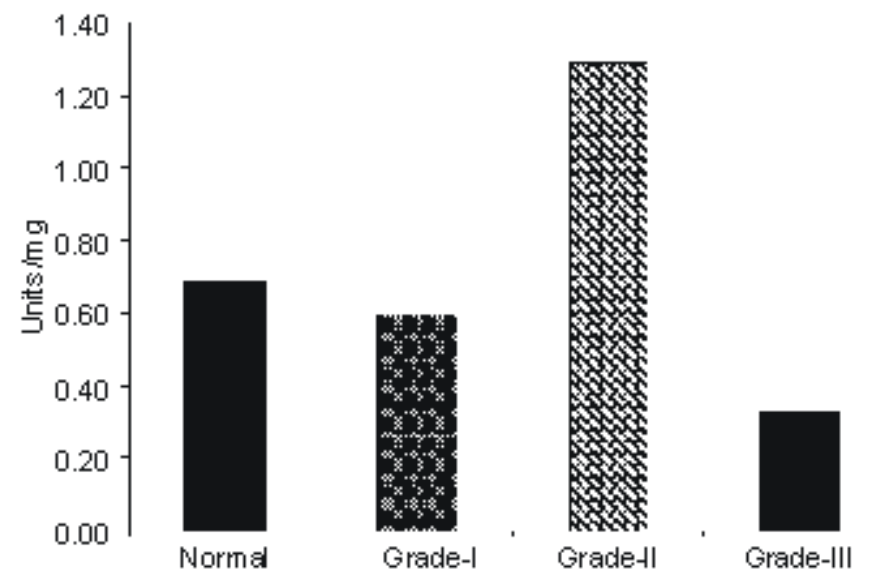

Fig. 6. Total LDH activity (unit/mg tissue) in cervix tissues of normal woman and patients suffering from cancer cervix (Grade-I, Grade-II and Grade-III)

Appearance of two additional new fractions were observed in the serum and cervical tissues of Grade-II patients. It is inferred that the intensity of cervix cancer increased with increased LDH pattern of serum and cervical tissues. Scoetens et al. (1964) found that two additional LDH isoenzymes in brain tumor. Klimove et al. (1989) observed seven LDH isoenzyme fractions in uterus cancer patients. Presence of multi isoenzyme forms of $\mathrm{LDH}$ and its variations in brain tumor enhanced the potentialities in neoplastic processes. The occurrence of addi-tional LDH fractions in cervix cancer patients may be the result of malignancy (Cori and Cori 1925). Increase in total serum and cervical tissue LDH activity was mainly due to genomic changes during malignant transformation. Main reason for increased LDH bands was mainly due to increased mitotic index and tumor cells also produce more amount of lactic acid. Increase of LDH level was mainly due to the break down of glycoprotein into lactic acid formation.

Reports of Grade-III showed an appearance of only three LDH fractions and disappearance of two LDH fractions (Pandit et al. 1990). Bhatnagar et al. (1983) reported that $\mathrm{LDH}_{1}$ and $\mathrm{LDH}_{5}$ are inhibited by the factors arising out of cervical cancer in patients suffering from breast 
and cervical cancer. It is suggested that advance stage of cervical cancer has tremendous influence in preventing LDH activity both qualitatively and quantitatively. This may lead to decreased lactate to pyruvate conversion resulting in anomaly in the regeneration of $\mathrm{NAD}^{+}$which may interfere with glycolysis part of carbohydrate metabolism. LDH isoenzyme determination in carcinoma cervix is an important prognostic parameter (Kumar et al. 1988). LDH activity in vaginal secretion is a diagnostic criterion which detects cancer (Horbach et al. 1984). Augoff and Grabowski (2004) were found out LDH isoenzyme and its clinical significance are very much useful in diagnosis and prognosis of neoplastic diseases. Niklasson et al. (1981) were reported that the Lactate dehydrogenase (LD) enzyme techniques proved to be more accurate than cytology with approximately the same number of false positives.

\section{CONCLUSION}

The variation in electrophoretic mobility and changes in the total LDH activity in cervical carcinoma patients were found in serum and cervical tissue samples. The appearance of two new additional fractions in Grade-II patients and disappearance of two fractions in the Grade-III patients suggest that Lactate dehydrogenase (LDH) isoenzyme is one of the important biochemical tumor marker in cervical carcinoma patients for diagnosis and to assess the grade of malignancy.

\section{ACKNOWLEDGEMENT}

The authors sincerely acknowledged to the Director, the directorate of medical education for granting permission to collect blood and biopsy samples from Cancer cervix patients at Government Arignar Anna Memorial Cancer Institute and Hospital, Kanchipuram.

\section{REFERENCES}

Augoff K, Grabowski K 2004. Significance of lactate dehydrogenase measurements in diagnosis of malignancies. Pol Merkur Lekarski, 17(102): 644-647.

Bhatnagar A, Meena, Satyanand, Madhava PK, Sarma Usha P, Murthy SP 1983. Serum lactate dehydrogenase and its isoenzymes in malignancies. Indian J Med Res, 78: 127.

Chow SN, Wu CC, Huang SC, Tsai YL, Chein CH 1991. Combined analysis of serum lactic dehydrogenase levels and isoenzyme patterns in ovarian neoplasm.
Proe Natl Sci Counc Repub Chin B, 15(2): 101104.

Cori CF, Cori GT 1925. Carbohydrate metabolism of tumours. II. Changes in sugar, lactic acid and oxygen combining power of blood passing through tumours. J Biol Chem, 65: 397-405.

Egami H, Takeshita I, Fukui M, Kitamura K 1983. Lactate dehydrogenase isoenzymes in human glioma. $J$ Neurol Sci, 61: 1-12.

George MA, 1978. Carcinoma of the ovary and serum lactic dehydrogenase levels. Surg Gynecol Obset, 146: 893-896.

Goldman RD, Kalpan NO, Hall TC 1964. Clinical Laboratory Methods. JD Bauer (Ed.): 1982. St. Louis: C.V. Mosby Company, P. 578.

Horbach L, Hilgarth M, Melchert F, Stegner HE 1984. Diagnostic value of increased lactate dehydrogenase activity in vaginal secretions for the early detection of diseases requiring treatment of the female genitals and breast. Geburtshilfe Frauenheilkd, 44(10): 627635.

King J 1965. In Practical Clinical Enzymology. P. 106. London: Von Nostrand D, Company Ltd.

Klimove IA, Serdiukov AS, Elistratova NB 1989. Lactate dehydrogenase isoenzymes in radiation therapy of cancer patients. Lab Delo, 7: 16-17.

Kumar M, Birdi A, Gupta YN, Gupta S 1988. Serum lactic dehydrogenase isoenzymes alternation in carcinoma cervix uteri. Int J Gynaecol Obset, 27(1): 91-95.

Lampl Y, Paniviz Y, Eshel Y 1990. LDH isoenzymes in CSF in various brain tumours. Neurol Neurosurg Psychiat, 53: 697-699.

Nair BS, Pillai R 1992. Oncogenesis of squamous carcinoma of the uterine cervix. International Journal of Gynecol Pathol, 11(1): 47-57.

Niklasson O, Skude G, Johansson R, Stormby N 1981. Screening of endometrial carcinoma by lactate dehydrogenase isoenzyme analysis of uterine fluid. Acta Obstet Gynecol Scand, 60(1): 1-8.

Nugmanov EV, Uteshev AB,Dzhilikbaeva RN 1981. Changes in lactate dehydrogenase activity in cervical precancer and cancer. Vapr Onkol, 27(9): 27 - 30.

Oladipo OO, Ajala MO, Afonja OA 2002. The lactate dehydrogenases in malignant and non malignant diseases. Niger Postgrad Med J, 9(1): 1-6.

Pandit MK, Joshi BH, Patel PS, Chitnis KE, Balar DB 1990. Efficacy of serum lactate dehydrogenase and its isoenzymes in monitoring the therapy in patients with acute leukemia. Indian J Pathol Microbiol. 33(1): 41-47.

Patel PS, Rawal GN, Balar DB 1993. Importance of serum sialic acid and lactate dehydnogenase in diagnosis and treatment monitoring of cervical cancer patients. Gynecol Oncol, 50(3): 294-299.

Pui CH, Dodge RK, Dahl GV, Rivera G, Thomas Look AT, Kalwinsky D, Bowman WP, Ochs J, Abromowitch M, Mirro J, Murphy SB 1985. Serum lactic dehydrogenase level has prognostic value in childhood acute Iymphoblastic leukemia. Blood, 66: 778-782.

Scoetens A, Karcher D, Van Sande M, Lowenthal A, 1964. Presence of additional lactate dehydrogenase isoenzyme in two cases of brain tumour. In: R Rutssan, L Vanden Driessche (Eds.): Enzymes in 
Clinical Chemistry. Amsterdam: Elsevier Publishing Company, pp. 130-133.

Talageri VR 1977. Evaluation of plasma LDH isoenzymes in cancer patients. Qualitative and quantitative assessment in patients with oral cancers and osteo sarcoma. Indian J Cancer, 14: 50.

Von Eyben FE 2001. A systematic review of lactate dehydrogenase isoenzyme 1 and germ cell tumors Clin Biochem, 34(6): 441-454.

Warburg O 1956. On the origin of cancer cell. Science, 123: 309-314

Wood DC, Verala V, Palmquist M, Weber R 1973. Serum lactic dehydrogenease and isoenzyme changes in clinical cancer. J Surg Oncol, 5: 251 - 257.

Wright EJ, Cawley LP, Eberhard TL 1966. Clinical application and interpretation of the serum lactate dehydrogenase zymogram. Am J Clin Pathol, 45: 737.

Xi MR, Peng ZL, Cao ZY 1994. The values of urine cystenie protein activity in the diagnosis of ovarian cancer. Chung Hua Fu Chan Ko Tsa Chih, 29(2): 85-87, 123.

Zar HH 1984. Biostatistical Analysis, USA: Prentice Hall Inc. 